\title{
IMPORTANCE OF RESULTS OBTAINED FROM GEOTECHNICAL MONITORING FOR EVALUATION OF REINFORCED SOIL STRUCTURE - CASE STUDY
}

\author{
M. Drusa ${ }^{\mathrm{a}, *}$, J. Vlcek $^{\mathrm{a}}$ \\ ${ }^{\text {a }}$ University of Zilina, Faculty of Civil Engineering, Department of Geotechnics, Univerzitna 8215/1, 01001 Zilina, Slovak Republic
}

Received: 09.03.2016 / Accepted: 03.04.2016 / Revised: 19.05.2016 / Available online: 31.05.2016

DOI: 10.1515/jaes-2016-0002

KEY WORDS: wall-face deformations, FEM, geotechnical monitoring, inclinometer

\begin{abstract}
:
In the case of realized geotechnical monitoring (GTM) of reinforced retaining wall in difficult geological conditions is demonstrated the important role at realisation of transport infrastructures, which are often realized in insufficient quality due to inappropriate geotechnical parameters from survey works or not fitted well design of structure at certain conditions. This can result in large deformations of structure, or losing stability or structure life-time is very limited and remediation work is complicated and expensive. There was built on the modernized railway line Bratislava - Trenčín, closed to Zlatovce, overpass and connected road embankments on the route of first class I/61. Structure was designed as a bridge over the railway track before the northern portal of the railway tunnel Turecký vrch was open. A part of the embankment and overpass was a retaining wall reinforced by geosynthetics. The results of the geotechnical monitoring of this wall were afterwards simulated using finite element method (FEM) and results of this comparison are the scope of this article.
\end{abstract}

\section{INTRODUCTION}

The example of the interesting construction of the retaining wall built during the modernization of the railway line in unfavourable engineering geological conditions was used to monitor the states of the wall during its construction and after its completion, which were then compared with direct measurements from the realized geotechnical monitoring.

The construction of the retaining wall was necessary to secure embankment body in this limited profile. The wall was designed to be reinforced with geosynthetics with modification of its face using precast concrete elements, which were based on reinforced concrete. Considering the adverse conditions of the foundation, the embankment was based on a geo-plate with precast vertical geodrains in the subsoil to accelerate the consolidation of the embankment. No specific requirements for realization of the monitoring were defined, so the plan of monitoring was left to the person in charge of the monitoring works.

\footnotetext{
*Corresponding author, e-mail: marian.drusa@fstav.uniza.sk
}

\section{GEOTECHNICAL MONITORING}

The aim of the monitoring was the verification of project assumptions of the behaviour of the construction, especially risks associated with the building of the embankment on subsoil with low bearing capacity (Drusa, 2015; Decký, 2013).

The measurements of subsoil displacements in the horizontal plane were carried out using a vertical inclinometer device, while the shifts in the vertical plane were examined using a sliding deformeter (Gróf, 2011; Segalini, 2015). Several geodetic methods for measuring displacement of building structures were employed according to national and European standard for measuring of surface deformations (Decký, 2015). Surface deformation of reinforced retaining walls with rigid face must follow these tolerances:

- $\pm 5 \mathrm{~mm} / 1 \mathrm{~m}$ height of the structure,

- local vertical or horizontal surface buckling $\pm 20 \mathrm{~mm}$ / $4.5 \mathrm{~m}$ of height,

- horizontal displacement of the top of the wall \pm 15 $\mathrm{mm}$ from the comparative line, 
$\overline{\mathrm{GE}}$ DEGRUTER

- uneven settlement in the longitudinal direction $\leq$ $0.5 \%$.

Another important parameter according to European standards, which to be checked at design and realisation is content of the fine grains $\varnothing<0.08 \mathrm{~mm}$ in the materials backfill, where max value of contents is 5\% for permeable backfill and max. $35 \%$ for the coarse backfill. Content of particles below $0.02 \mathrm{~mm}$ must not exceed $10 \%$. Criteria for particle contents in backfill material are many times missed, which causes of occurrence of wet surface blocks at case of inappropriate drainage capacity of crushed stones at permeable zone in the contact of wall segments. Recommended length of this contact zone is from 0.6 $\mathrm{m}$ to $1 \mathrm{~m}$. Other limit condition control by maximal contents of fines good interaction of geogrids with backfill material.

There has been used triangulation method for position measuring, and height control was measured by very precise methods of levelling. For the detection of behaviour of the embankment, six measurement profiles were designed. Each profile was supplied with 5 geodetic marks for measurement of surface displacements. Two profiles situated at the highest point of the embankment were equipped with one inclinometer and one 3D inclinometer borehole (Segalini, 2015) designed for measurement of horizontal, as well as vertical displacements. New development in monitoring of slopes deformations offer to install inclinometers, which are enough precise and doesn't required special instrumentation (Das, 2014; Chebeň, 2015; Lamich, 2016; Yilmaz, 2014; Zgútová, 2012).

It was decided to build measurement devices, when top level of embankment was finished. This fact did not allow monitoring of the embankment during the construction process, but it was useful for stage of operation controlling (Zgútová, 2012). The measurements in the profiles were carried out in monthly intervals. Overall, twelve measurements including the fundamental measurement were realized.

Considering the fact that the monitoring was realized only after the completion of the embankment, it can be predicted that the magnitude of displacements is quite small. This is confirmed by the measurements, in which the values of horizontal displacements in boreholes reached maximum of $2-3 \mathrm{~mm}$ in both directions, with the exception of small depth under the terrain at the foot of the retaining wall, where these reached 7 $\mathrm{mm}$ in magnitude. These displacements are caused by the concentration of stresses in lower side of the retaining wall. The displacements kept on growing, while a certain degree of deceleration of their growth could be observed.

\section{SIMULATION OF RESULTS OF GEOTECHNICAL MONITORING}

The question arises why a simulation is needed for a successful realization of a structure. Firstly, it is the calibration of input parameters involved at designing of the structure and secondly important for geotechnical modelling is the confirmation of the ability of FEM models to be precise with respect to the real behaviour of structures in difficult geotechnical conditions.

The results of the monitoring were correlated with the FEM modelling by software PLAXIS 2D. The software is able to capture the process of construction of the embankment and its consolidation and then monitor variables at various points of the structure. For the purposes of modelling, the profile at which the retaining wall reaches the height of $6 \mathrm{~m}$ was selected (Figure 1).

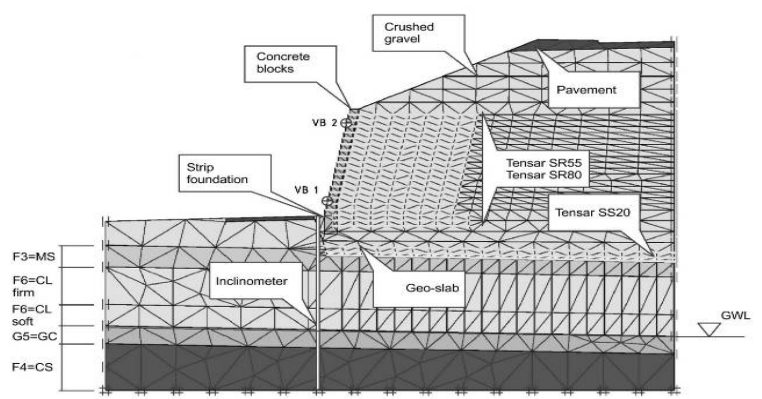

Figure 1. Model for the FEM modelling with the inclinometer and the geodetic marks

Geological profile and properties of the soils were derived from the results of geotechnical survey and tests carried out on partial layers of the embankment. The 15 -node elements were used in the analysis and consolidation method of calculation of deformation was selected. Consolidation method allowed updating the mesh and the pore pressures during construction stages and also the reaction of subbase layers on load increase (Drusa, 2015).

Updating the mesh includes a secondary effect of deformation, which takes into account the geometry changes in cases of large deformation, which have a positive impact on the stability of the structure. Such adjustment of calculation simulates real behaviour of the structure at construction process. Update of the pore pressures takes into account settlement of saturated clayey layers over bedrock and subsequent buoyancy effect of water that reduces the effective stress at soil layers of embankment. The calculation was divided into several phases for detailed consideration during the construction of the embankment and its subsequent consolidation, with intervals of phases corresponding with the actual progress of work. For direct comparison of modelling output with data obtained from geotechnical monitoring, values of calculated deformation were subtracted directly from the model at places of inclinometer borehole and surveying marks (Lamich, 2016).

Parameters of the materials are shown in Tables 1 to 3. For soil and concrete structures, material model Mohr-Coulomb (MC) was selected.

\begin{tabular}{|l|l|c|c|l|}
\hline \multicolumn{1}{|c|}{ Parameter } & $\begin{array}{c}\text { Soil } \\
\text { class / } \\
\text { unit }\end{array}$ & $\begin{array}{c}\text { F6=CL } \\
\text { firm }\end{array}$ & $\begin{array}{c}\text { F6 }=\mathrm{CL} \\
\text { soft }\end{array}$ & \multicolumn{1}{c|}{ Units } \\
\hline Material model & Model & MC & MC & - \\
\hline Permeability & & Undrained & Undrained & - \\
\hline $\begin{array}{l}\text { Unit weight above } \\
\text { GWL }\end{array}$ & $\gamma$ & 19 & 19.5 & $\mathrm{kN} / \mathrm{m}^{3}$ \\
\hline $\begin{array}{l}\text { Unit weight below } \\
\text { GWL }\end{array}$ & $\gamma_{\text {sat }}$ & 20 & 20.5 & $\mathrm{kN} / \mathrm{m}^{3}$ \\
\hline $\begin{array}{l}\text { Horizontal } \\
\text { permeability }\end{array}$ & $k_{x}$ & 0.010 & 0.010 & $\mathrm{~m} / \mathrm{day}$ \\
\hline $\begin{array}{l}\text { Vertical } \\
\text { permeability }\end{array}$ & $k_{y}$ & 0.001 & 0.001 & $\mathrm{~m} / \mathrm{day}$ \\
\hline Young's modulus & $E_{\text {ref }}$ & $4 \times 10^{3}$ & $2 \times 10^{3}$ & $\mathrm{kN} / \mathrm{m}^{2}$ \\
\hline Poisson's ratio & $v$ & 0.35 & 0.35 & - \\
\hline
\end{tabular}




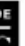
DE GRUYTER

\begin{tabular}{|l|l|c|c|l|}
\hline Cohesion & $c$ & 15 & 10 & $\mathrm{kN} / \mathrm{m}^{2}$ \\
\hline Friction angle & $\varphi$ & 20 & 18 & $\circ$ \\
\hline Dilatancy angle & $\psi$ & 0 & 0 & $\circ$ \\
\hline Reduction factor & $R_{\text {inter }}$ & 0.7 & 0.7 & - \\
\hline
\end{tabular}

Table 1. The parameters of the subsoil

\begin{tabular}{|l|l|c|c|l|}
\hline Parameter & $\begin{array}{l}\text { Soil } \\
\text { class / } \\
\text { unit }\end{array}$ & G5=GC & R6/F4=CS & Units \\
\hline Material model & Model & MC & MC & - \\
\hline Permeability & & Drained & Undrained & - \\
\hline $\begin{array}{l}\text { Unit weight above } \\
\text { GWL }\end{array}$ & $\gamma$ & 18 & 19.5 & $\mathrm{kN} / \mathrm{m}^{3}$ \\
\hline $\begin{array}{l}\text { Unit weight below } \\
\text { GWL }\end{array}$ & $\gamma_{\text {sat }}$ & 19.5 & 20.5 & $\mathrm{kN} / \mathrm{m}^{3}$ \\
\hline $\begin{array}{l}\text { Horizontal } \\
\text { permeability }\end{array}$ & $k_{x}$ & 20 & 0.010 & $\mathrm{~m} / \mathrm{day}^{3}$ \\
\hline $\begin{array}{l}\text { Vertical } \\
\text { permeability }\end{array}$ & $k_{y}$ & 2 & 0.001 & $\mathrm{~m} / \mathrm{day}$ \\
\hline Young‘s modulus & $E_{\text {ref }}$ & $50 \times 10^{3}$ & $4 \times 10^{3}$ & $\mathrm{kN} / \mathrm{m}^{2}$ \\
\hline Poisson's ratio & $v$ & 0.3 & 0.35 & - \\
\hline Cohesion & $c$ & 5 & 15 & $\mathrm{kN} / \mathrm{m}^{2}$ \\
\hline Friction angle & $\varphi$ & 30 & 15 & $\circ$ \\
\hline Dilatancy angle & $\psi$ & 0 & 0 & $\circ$ \\
\hline Reduction factor & $R_{\text {inter }}$ & 0.9 & 0.8 & - \\
\hline
\end{tabular}

Table 1. The parameters of the subsoil (continue)

\begin{tabular}{|l|l|l|l|l|}
\hline Parameter & Name & $\begin{array}{l}\text { Tensar } \\
\text { SS 20 }\end{array}$ & $\begin{array}{l}\text { Geo-slab } \\
\text { reinforcement }\end{array}$ & Units \\
\hline Material model & Model & $\begin{array}{l}\text { Linear } \\
\text { elastic }\end{array}$ & $\begin{array}{l}\text { Linear } \\
\text { elastic }\end{array}$ & - \\
\hline Axial stiffness & EA & 350 & 1700 & $\mathrm{kN} / \mathrm{m}$ \\
\hline
\end{tabular}

\begin{tabular}{|l|l|l|l|l|}
\hline \multicolumn{1}{|c|}{ Parameter } & \multicolumn{1}{|c|}{ Name } & $\begin{array}{c}\text { Tensar } \\
\text { SR 55 }\end{array}$ & \multicolumn{1}{c|}{$\begin{array}{c}\text { Tensar } \\
\text { SR 80 }\end{array}$} & \multicolumn{1}{c|}{ Units } \\
\hline Material model & Model & $\begin{array}{l}\text { Linear } \\
\text { elastic }\end{array}$ & Linear elastic & - \\
\hline Axial stiffness & EA & 750 & 1000 & $\mathrm{kN} / \mathrm{m}$ \\
\hline
\end{tabular}

Table 2. The parameters of the reinforcements

\begin{tabular}{|l|l|l|l|l|}
\hline \multicolumn{1}{|c|}{ Parameter } & Unit & \multicolumn{1}{c|}{$\begin{array}{c}\text { Concrete } \\
\text { foundation }\end{array}$} & $\begin{array}{c}\text { Concrete } \\
\text { blocks }\end{array}$ & \multicolumn{1}{c|}{ Units } \\
\hline Material model & & MC & MC & - \\
\hline Permeability & & Non-porous & Non-porous & - \\
\hline $\begin{array}{l}\text { Unit weight } \\
\text { above GWL }\end{array}$ & $\gamma$ & 25 & 24 & $\mathrm{kN} / \mathrm{m}^{3}$ \\
\hline $\begin{array}{l}\text { Unit weight } \\
\text { below GWL }\end{array}$ & $\gamma_{\text {sat }}$ & - & - & $\mathrm{kN} / \mathrm{m}^{3}$ \\
\hline $\begin{array}{l}\text { Horizontal } \\
\text { permeability }\end{array}$ & $k_{x}$ & - & - & $\mathrm{m} /$ day \\
\hline $\begin{array}{l}\text { Vertical } \\
\text { permeability }\end{array}$ & $k_{y}$ & - & - & $\mathrm{m} / \mathrm{day}$ \\
\hline $\begin{array}{l}\text { Young's } \\
\text { modulus }\end{array}$ & $E_{\text {ref }}$ & $31 \times 10^{6}$ & $32 \times 10^{6}$ & $\mathrm{kN} / \mathrm{m}^{2}$ \\
\hline Poisson's ratio & $v$ & 0.2 & 0.2 & - \\
\hline Cohesion & $c$ & 500 & 580 & $\mathrm{kN} / \mathrm{m}^{2}$ \\
\hline Friction angle & $\varphi$ & 35 & 35 & ${ }^{6}$ \\
\hline Dilatancy angle & $\psi$ & - & - & $\circ$ \\
\hline $\begin{array}{l}\text { Reduction } \\
\text { factor }\end{array}$ & $R_{\text {inter }}$ & - & - & - \\
\hline
\end{tabular}

Table 3. The parameters of the embankment materials

\begin{tabular}{|l|l|l|l|l|}
\hline \multicolumn{1}{|c|}{ Parameter } & $\begin{array}{c}\text { Soil } \\
\text { class / } \\
\text { unit }\end{array}$ & $\begin{array}{c}\text { Crushed } \\
\text { stones } \\
0 / 63\end{array}$ & \multicolumn{1}{|c|}{ Pavement } & \multicolumn{1}{|c|}{ Units } \\
\hline Material model & Model & MC & MC & - \\
\hline Permeability & & Drained & Non-porous & - \\
\hline $\begin{array}{l}\text { Unit weight } \\
\text { above GWL }\end{array}$ & $\gamma$ & 19.5 & 23 & $\mathrm{kN} / \mathrm{m}^{3}$ \\
\hline $\begin{array}{l}\text { Unit weight } \\
\text { below GWL }\end{array}$ & $\gamma_{\text {sat }}$ & 21 & 23.5 & $\mathrm{kN} / \mathrm{m}^{3}$ \\
\hline $\begin{array}{l}\text { Horizontal } \\
\text { permeability }\end{array}$ & $k_{x}$ & 100 & 0.001 & $\mathrm{~m} / \mathrm{day}$ \\
\hline $\begin{array}{l}\text { Vertical } \\
\text { permeability }\end{array}$ & $k_{y}$ & 50 & 0.0001 & $\mathrm{~m} / \mathrm{day}$ \\
\hline $\begin{array}{l}\text { Young's } \\
\text { modulus }\end{array}$ & $E_{\text {ref }}$ & $150 \times 10^{3}$ & $2 \times 10^{6}$ & $\mathrm{kN} / \mathrm{m}^{2}$ \\
\hline Poisson's ratio & $v$ & 0.3 & 0.35 & - \\
\hline Cohesion & $c$ & 0,1 & 300 & $\mathrm{kN} / \mathrm{m}^{2}$ \\
\hline Friction angle & $\varphi$ & 32 & 30 & $\circ$ \\
\hline Dilatancy angle & $\psi$ & 2 & 0 & $\circ$ \\
\hline Reduction factor & $R_{\text {inter }}$ & 0.9 & 0.8 & - \\
\hline
\end{tabular}

Table 3. The parameters of the embankment materials (continue)

The material model of the geogrid reinforcement was considered to be elastic with respect to small predicted strains, which are limited by the requirements of technical standards. The values of axial stiffness for the geogrids were determined based on the results of the tests of these reinforcements, where the required value of stiffness EA $(J)$ was determined as the force applied by the reinforcement and the strain $F /(\Delta l / l)$ at elongation of $1 \%$. The time development in inclinometer borehole at the foot of the retaining wall and the corresponding transversal displacements are presented in Figure 2.

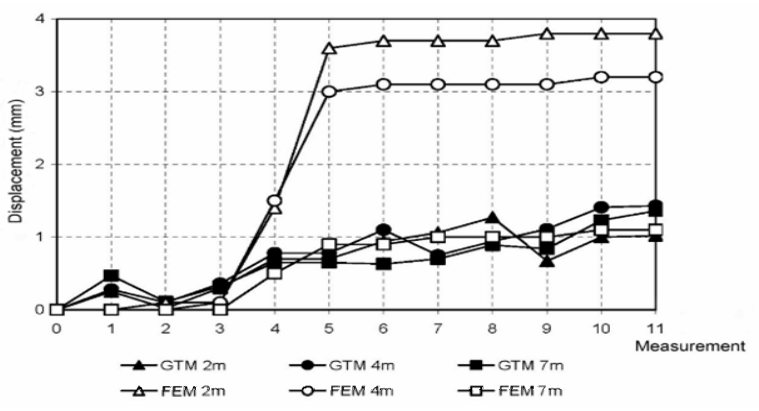

Figure 2. Development of the transversal displacements in the inclinometer and in the FEM model in the depth of 2, 4 and $7 \mathrm{~m}$ under the terrain

The results of modelling using FEM can be considered relevant with respect to the results of the monitoring (GTM). The deviations in the results are seen especially in the layers of silt and clay soils in the depth of $2 \mathrm{~m}$ and $4 \mathrm{~m}$, where the use of more advanced material model would increase the accuracy of the results. However, this model requires more input data, which are not determined in-situ or later in lab, so they were not available in this case. On the other hand, it can be seen that Mohr-Coulomb model is sufficient for modelling of sandy, gravely soils. From the results of displacements for depth of 7 $\mathrm{m}$, close enough results of monitoring and modelling can be 


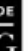
DE GRUYTER

observed. According to geological profile, this depth corresponds to a layer of saturated clayey gravel.

From plotted line in the graph can be seen moment of installation of pavement layers. This fact was indicated by the increased values of displacements between the $3 \mathrm{rd}$ and the 4 th measurement in both monitoring as well as modelling (Figure 2).

Geodetic measurements in the given profile consist of vertical measurements at the point VB 1 and position measurements at point VB 2, with derivation of transversal deformation perpendicular to the embankment axis (Figures 3 and 4).

Survey data are represented in that profile by precise height measurement at point VB 1 and position measurements at point VB 2 for the determination of lateral displacement perpendicular to the axis of the embankment vertical alignment (Figures 3 and 4).

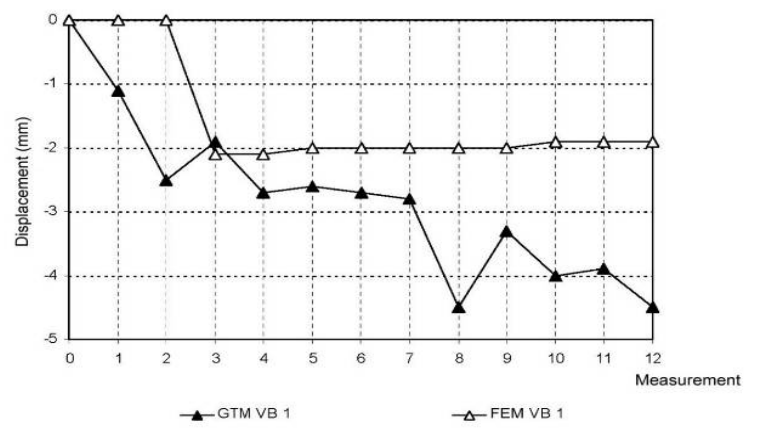

Figure 3. Development of the vertical displacements of the point VB1 measured on the geodetic marks on the embankment and in the FEM model

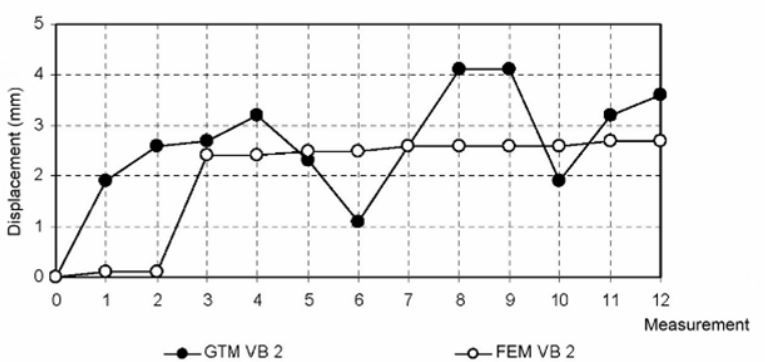

Figure 4. Development of the vertical displacements of the point VB2 measured on the geodetic marks on the embankment and in the FEM model

Comparison of the results from both the monitoring and the modelling showed that FEM is a suitable tool for analysis of the reinforced soil structures, including the retaining walls of transport infrastructure. The results of modelling are close to the results obtained from the monitoring, whereas the monitoring alone was carried out without sufficient calibration of the model, only with the use of data acquired from geotechnical survey and in-situ tests.

\section{CONCLUSIONS}

Simulation of results of geotechnical monitoring using FEM analyses shows that the selected methods allows high enough prediction of behaviour of simulated structures. The deviations between results of the monitoring and outputs of modelling were caused by the imperfections of the construction and necessity of generalization and simplification of basic relationships, soil construction and phases of calculations to allow calculation procedures to be done without any instabilities of calculation process or unusual behaviour of the model (Drusa, 2015).

The modelling alone does not replace the full value of geotechnical monitoring for more complex structures and basic relationships. For the purposes of creating the most fitting calculation models, it is necessary to analyse the majority of data from the monitored structures, which in turn results in more knowledge gained for the purposes of creating a model that describes the most realistic behaviour of the structure even before the start of the construction. Even though these methods require more extensive input data in some cases, the general trend in the field of geotechnics is to realize proposals without any additional overdesign of structures, which is only possible at thorough analysis of the risks present in the geological environment with respect to the properties of the used materials.

Based on the modelling, following points can be stated:

- FEM allows prediction of the behaviour of the structure with sufficient accuracy before the start of the construction works,

- FEM enables the optimization of the design of the structure, as well as the technology and the construction phases for compliance with the conditions of service ability limit state (SLS) (Das, 2014; Drusa, 2015).

- Modelling using FEM allows easy measurement of the required parameters at any point of the model, whereas analytical methods do not allow this or require more complicated steps for acquiring them.

\section{REFERENCES}

Das B., Sobhan K., 2014. Principle of Geotechnical Engineering, 8th Edition, Cengage Learning, ISBN 10:1-13311089-4.

Decký, M., Drusa, M., Pepucha, L., Zgútová, K., 2013. Earth Structures of Transport Constructions. Pearson Education Limited 2013, Edinburg Gate, Harlow, Essex CM20 2JE, p. 180, ISBN 978-1-78399-925-5.

Drusa M., 2015. Numerical verification of geotechnical structure in unfavourable geological conditions - case study. Geoscience Engineering, Vol. 61(2015), No 2. p. 8-13 ISSN 1802-5420.

Gróf, V., 2011. Geotechnical monitoring SO 24-38-01 Nové Mesto nad Váhom - Trenčianske Bohuslavice, Communication of the overpass in nrkm 104,346 including retaining wall (In Slovak). Žilina: Geoexperts.

http://www.solexperts.com $\quad 02 / 2016$ 
Chebeň V., Drusa M., Kuba M., 2015. Int. J. of GEOMATE, Sept., 2015, Vol. 9, No. 1 (Sl. No. 17), pp. 1428-1433. Geotech., Const. Mat. and Env., ISSN:2186-2982(P), 21862990(O), Japan.

Lamich, D., Marschalko, M., Yilmaz, I., Bednářová, P., Niemiec, D., Kubečka, K., Mikulenka, V., 2016. Subsidence measurements in roads and implementation in land use plan optimisation in areas affected by deep coal mining. Environmental Earth Sciences, Volume 75, Issue 1, 1 January 2016, Article number 69, Pages 1-11.

Segalini, A, Chiapponi, L, Pastarini, B., 2015. Application of modular underground monitoring system (MUMS) to landslides monitoring: Evaluation and new insights. Engineering Geology for Society and Territory - Volume 2: Landslide Processes, Springer Int. Publ., DOI: 10.1007/978-3-319-09057-3

Slabej, M., Grinč, M., Kováč, M., Decký, M., Šedivý, S., 2015. Non-invasive diagnostic methods for investigating the quality of Zilina airport's runway. 2015 Contributions to Geophysics and Geodesy, Volume 45, Issue 3, 1 September 2015, Pages 237-254, VEDA ISSN: 13352806

Yilmaz I, Marschalko M, Lamich D., Drusa M, Machačík J., Heviánková S, Kyncl M, Lacková E, Bestová E, Krčmář D, Stutz E, Bednárik M., 2014. Monitoring of heat transmission from buildings into geological environment and evaluation of soil deformation consequences in foundation engineering. Environmental Earth Sciences, March 2014, ISSN-Online 1866-6299, Print ISSN 1866-6280, DOI 10.1007/s12665-0143200-2, Springer-Verlag Berlin Heidelberg 2014 (IF 2012$1,445)$.

Zgútová, K., Decký, M., Ďureková, D., 2012. Non-Destructive Determining CBR Values of Ground Structures of Engineering Constructions. 12th International Multidisciplinary Scientific GeoConference, www.sgem.org, SGEM2012 Conference Proceedings, ISSN 1314-2704, June 17-23, 2012, Vol. 4, pp. $107-116$. 